\title{
Response of rhizomes of the invasive Hedychium coronarium J. König (Zingiberaceae) to different soil moisture conditions
}

\author{
Wagner Antonio Chiba de Castro* (D), Renata Vilar de Almeida² (D), Rafael de Oliveira Xavier ${ }^{3}$ (D), Marcos Arduin ${ }^{4}$ (D), \\ Hamilton Macacari Moya ${ }^{5}$ (D) and Dalva Maria da Silva Matos $^{5}$ (D)
}

Received: July 20, 2020

Accepted: January 11, 2021

\begin{abstract}
The ability to maintain high competitiveness under a wide range of conditions is common among successful invasive species. The performance of rhizomatous macrophytes in different habitats is closely related to morphological and physiological adaptations in the rhizome system. We investigated the effects of soil moisture conditions on the microstructure of rhizomes of Hedychium coronarium (Zingiberaceae), an aggressive invader of Neotropical riparian sites. We collected rhizome fragments of $H$. coronarium and soil samples in wet and dry regions of riparian areas dominated by this species in southeastern Brazil. We measured soil moisture content gravimetrically and rhizome fragments were fixed, sectioned, and stained for histological analysis. Only rhizomes from wet regions exhibited aerenchyma, whereas amyloplasts were much more abundant and larger in rhizomes from dry regions than in rhizomes from wet regions. Even though low starch content in wet soils indicates the occurrence of anaerobic metabolism, the presence of aerenchyma may contribute to the typically high performance of $H$. coronarium in waterlogged soils. Although further studies are needed to assess how responses at the rhizome level affect the competitive ability of $H$. coronarium, our findings show that they may play a role in the dominance of this species in Neotropical riparian sites.
\end{abstract}

Keywords: aerenchyma, amyloplasts, invasive macrophytes, riparian floodplains, soil hypoxia

The successful establishment of aquatic macrophytes depends on their tolerance to the excess and lack of water (Levitt 1980). This tolerance is often associated with morphological and physiological adaptations to cope with changes in the aquatic environment (Sultan 2003), which may originate from adaptive evolution to local conditions,

1 Instituto Latino-Americano de Ciências da Vida e da Natureza, Universidade Federal da Integração Latino-Americana, 85867-970,

Foz do Iguaçu, PR, Brazil

2 Secretaria de Estado de Educação e Desporto do Amazonas, 69076-830, Manaus, AM, Brazil

3 Instituto de Biologia, Universidade de Campinas, 13083-862, Campinas, SP, Brazil

4 Departamento de Botânica, Universidade Federal de São Carlos, 13565-905, São Carlos, SP, Brazil

5 Departamento de Hidrobiologia, Universidade Federal de São Carlos, 13565-905, São Carlos, SP, Brazil

*Corresponding author: wagner.castro@unila.edu.br 
phenotypic plasticity, or a combination of both mechanisms (Davidson et al. 2011; VanWallendael et al. 2018). Among invasive macrophytes, the ability to spread and become dominant in new habitats is often closely related to rhizome adaptations (Weber 2011). Therefore, investigating morphological and physiological responses of invasive species to variability in the introduced range is essential to understand the drivers of invasion success (Williams et al. 2008). We investigated the influence of differences in soil moisture on the microstructure of rhizomes of Hedychium coronarium J. König (Zingiberaceae). Hedychium coronarium, commonly known as white ginger lily, is an up to $2 \mathrm{~m}$ high rhizomatous macrophyte native to tropical Asia (Kissmann 1997; Macedo 1997). The species has been widely introduced elsewhere as an ornamental plant (Kissmann 1997) and is an aggressive invasive species in Brazil's riparian sites (Chibade-Castro et al. 2016). Given the success of H. coronarium in Neotropical wetlands, we expected that its rhizomes would show histological adaptations to cope with soil hypoxia in response to high soil moisture.

The study was carried out in five floodplains of first or second order streams near the city of São Carlos (21 $30^{\circ}$ $22^{\circ} 30^{\prime} \mathrm{S} ; 47^{\circ} 30^{\prime}-48^{\circ} 30^{\prime} \mathrm{W}$ ), São Paulo state, southeastern Brazil. The sites were at least $5 \mathrm{~km}$ apart and located on different river systems bordered by riparian vegetation and fragments of semi-deciduous mesophytic forest and of savanna vegetation (cerrado) (Soares et al. 2003, see Figures 3 to 8 in Almeida (2015) for further site details). The regional climate is a transition between Cwa.i and Aw.i (Alvares et al. 2013 sensu Köppen-Geiger), with a dry season from April to September and a rainy season from October to March. The annual average temperature is $21.8^{\circ} \mathrm{C}$ and the annual average precipitation is $1,440 \mathrm{~mm}$ (Ferrari 2012). We randomly collected three rhizome fragments and three soil samples (5 to $10 \mathrm{~cm}$ deep) in the wet region (in the stream margin) and dry region (approximately $20 \mathrm{~m}$ distant from the stream) of each invaded site, resulting in 30 rhizome fragments and 30 soil samples overall. We mixed the three soil samples from each site to create a composite sample, so that there were 10 composite soil samples overall (five from wet regions and five from dry regions). We measured the soil moisture content gravimetrically after drying $50 \mathrm{~g}$ of each humid soil sample at $60^{\circ} \mathrm{C}$ for $48 \mathrm{~h}$ and compared values between wet and dry regions using a paired t-test. Rhizome fragments were cut into $5 \mathrm{~cm}$ segments, fixed in FormalinAcetic-Alcohol, progressively dehydrated in ethanol series (15 to $95 \%$ ) and embedded in glycol methacrylate historesin (Sims 1974). We transversely sectioned each processed rhizome at 4 to $7 \mu \mathrm{m}$ with a rotary microtome and stained the resulting sections with $1 \%$ thionine solution and Lugol reagent to detect starch. We photographed each rhizome section with an Olympus BX41 microscope. The percentage of cross-sectional area occupied by aerenchyma and amyloplasts was then quantified for each image using the ImageJ software. We calculated average percentages for the three rhizome fragments from each site, resulting in five values for wet regions and five for dry regions.

Soil moisture was two times lower in dry $(39.8 \% \pm$ standard deviation $=4.27)$ than in wet $(85.2 \% \pm 5.06)$ regions $(\mathrm{N}=5, \mathrm{t}=11.43, \mathrm{p}<0.001)$. For all sites, we found large histological differences between rhizomes removed from the dry and wet region (Fig. 1). The percentage of rhizome cross-sectional area occupied by aerenchyma tissue was close to $0 \%$ in rhizomes from dry regions (mean \pm standard deviation- $0.002 \pm 0.008 \%$, Fig. $1 \mathrm{~A}$ ) but was on average $11.4 \%( \pm 0.024)$ in rhizomes from wet regions (Fig. 1B). By contrast, amyloplasts occupied over $20.9 \%$ of the cross-sectional area in rhizomes from dry regions $( \pm 0.033$, Fig. $1 C)$, but occupied a very small area in rhizomes from wet regions $(0.004 \pm 0.018 \%$, Fig. 1D).

We found that rhizomes of $H$. coronarium exhibited both aerenchyma lacunae and low abundance of amyloplasts in response to high soil moisture conditions. The production of aerenchyma is stimulated by ethylene accumulation and facilitates oxygen conduction from aerial to submerged organs (Armstrong et al. 2000; Jung et al. 2008). Accordingly, aerenchyma is commonly found in hygrophytic species subjected to hypoxic or anoxic conditions (Chen et al. 2002; Sultan 2003; Leite et al. 2012), including the emergent macrophyte Typha angustifolia L. (Typhaceae), found throughout Brazil (Corrêa et al. 2015). Likewise, Maricle \& Lee (2002) reported that the highly invasive intertidal grass Spartina alterniflora Loisel (Poaceae) produced more aerenchyma in underground organs under flooding than in well-drained soils on the west coast of North America. However, in their study, the amount of aerenchyma shown by $S$. alterniflora in well-drained soils $(10 \%)$ was similar to what we found in rhizomes of $H$. coronarium collected in the wet region of riparian sites. Spartina grasses often grow vigorously under stressful conditions, such as saline and anoxic estuarine environments (Teal \& Teal 1969), and tolerates high $\mathrm{H}_{2} \mathrm{~S}$ levels (Lee 2003). Therefore, we believe that this discrepancy between the findings of Maricle \& Lee (2002) and our results could be attributed to differences in responses to oxygen depletion between the target species and/or in the local hydrological conditions.

Pan et al. (2012) associated low starch content in roots of emergent macrophytes subjected to flooding with increased consumption of carbohydrate due to fermentative metabolism. The most likely mechanism for this relationship is an increase in the activity of alcohol dehydrogenase and in the concentration of ethanol originated from ethylene as a result of flooding (Chen \& Qualls 2003). The demand for soluble sugar is expected to increase due to the inefficient use of glucose in this alcoholic fermentation, so that roots under flooding tend to have high concentration of soluble sugars and low concentration of starch (Chen et al. 2005). This mechanism is consistent with the low number of amyloplasts in rhizomes of $H$. coronarium from wet regions compared to those from dry regions, as the main source 

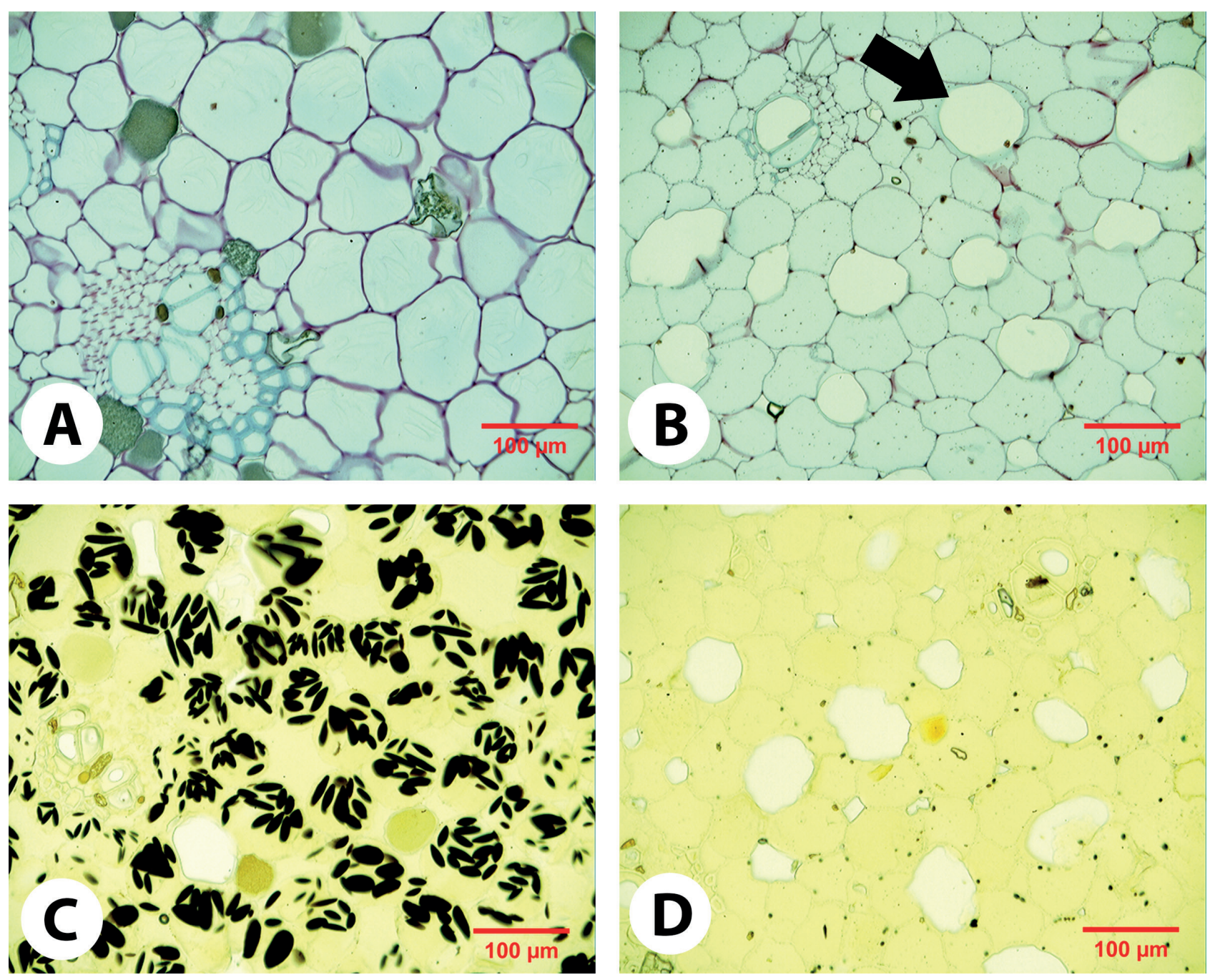

Figure 1. Transverse sections of rhizomes of $H$. coronarium collected under different soil moisture conditions in ten riparian sites in southeastern Brazil. Rhizome sections were stained either with a $1 \%$ tionine sollution (A and $\mathbf{B})$ or lugol reagent (C and $\mathbf{D})$. (A) Rhizome collected dry regions without aerenchyma. (B) Rhizome collected in wet regions showing aerenchyma. (C) Rhizome collected in dry regions showing large and numerous amyloplasts. (D) Rhizome collected in wet regions showing small and sparse amyloplasts.

of non-structural carbohydrates is the starch located in rhizome amyloplasts.

The occurrence of anaerobic metabolism in rhizomes of $H$. coronarium subjected to high soil moisture suggests that flooding can decrease the performance of this species. However, Neotropical riparian sites subjected to soil waterlogging are commonly dominated by this species and show low plant diversity and sparse tree cover (Chiba-deCastro 2014), possibly because negative effects of hypoxic conditions on $H$. coronarium are alleviated by the production of aerenchyma in the rhizomes (Mendelssohn et al. 1981). Although further studies are needed to assess the role of these mechanisms of tolerance to soil reduction in the competitive ability of $H$. coronarium and coexisting native macrophytes, we conclude that specific rhizome responses to soil moisture conditions may contribute to the success of this invader in the Neotropics.

\section{Acknowledgements}

We thank the Foundation for Research Support of the State of São Paulo (FAPESP - grant 2012/094854) and UNILA-PRPPG (Edital n80/2019) for funding the research.

\section{References}

Almeida RV. 2015. Invasividade de Hedychium coronarium J. Köenig (Zingiberaceae) em diferentes umidades do solo. MSc Thesis, Universidade Federal de São Carlos, São Carlos.

Alvares CA, Stape JL, Sentelhas PC, Moraes G, Leonardo J, Sparovek G. 2013. Köppen's climate classification map for Brazil. Meteorologische Zeitschrift 22: 711-728.

Armstrong W, Cousins D, Armstrong J, Turner DW, Beckett PM. 2000. Oxygen Distribution in Wetland Plant Roots and Permeability Barriers to Gas-exchange with the Rhizosphere: a Microelectrode and Modelling Study with Phragmites australis. Annals of Botany 86: 687-703. 


\section{Response of rhizomes of the invasive Hedychium coronarium J. König (Zingiberaceae) to different soil moisture conditions}

Chen H, Qualls RG, Blank RR. 2005. Effect of soil flooding on photosynthesis, carbohydrate partitioning and nutrient uptake in the invasive exotic Lepidium latifolium. Aquatic Botany 82: 250-268.

Chen H, Qualls RG, Miller GC. 2002. Adaptive responses of Lepidium latifolium to soil flooding: biomass allocation, adventitious rooting, aerenchyma formation and ethylene production. Environmental and Experimental Botany 48: 119-128.

Chen H, Qualls RG. 2003. Anaerobic metabolism in the roots of seedlings of the invasive exotic Lepidium latifolium. Environmental and Experimental Botany 50: 29-40.

Chiba-de-Castro W, Almeida R, Leite M, Marrs R, Matos DS. 2016. Invasion strategies of the white ginger lily Hedychium coronarium J. König (Zingiberaceae) under different competitive and environmental conditions. Environmental and Experimental Botany 127: 55-62.

Chiba-de-Castro WA. 2014. Ecologia da invasora Hedychium coronarium J. König (Zingiberaceae). PhD Thesis, Universidade Federal de São Carlos, São Carlos.

Corrêa FF, Madail RH, Barbosa S, et al. 2015. Anatomy and physiology of Cattail as related to different population densities. Planta Daninha 33: 01-12.

Davidson AM, Jennions M, Nicotra AB. 2011. Do invasive species show higher phenotypic plasticity than native species and, if so, is it adaptive? A meta-analysis. Ecology Letters 14: 419-431.

Ferrari AL. 2012. Variabilidade e tendência da temperatura e pluviosidade nos municípios de Pirassununga, Rio Claro, São Carlos e São Simão (SP): estudo sobre mudança climática de curto prazo em escala local. $\mathrm{PhD}$ Thesis, Universidade de São Paulo, São Paulo.

Jung J, Lee SC, Choi H-K. 2008. Anatomical patterns of aerenchyma in aquatic and wetland plants. Journal of Plant Biology 51: 428-439

Kissmann G. 1997. Plantas daninhas e nocivas. São Bernardo do Campo, BASF- Badische Anilin \& Soda Fabrik.

Lee RW. 2003. Physiological adaptations of the invasive cordgrass Spartina anglica to reducing sediments: rhizome metabolic gas fluxes and enhanced $\mathrm{O}_{2}$ and $\mathrm{H}_{2} \mathrm{~S}$ transport. Marine Biology 143: 9-15.
Leite K, França F, Scatena VL. 2012. Structural variations among monocot emergent and amphibious species from lakes of the semi-arid region of Bahia, Brazil. Brazilian Journal of Biology 72: 163-169.

Levitt J. 1980. Responses of Plants to Environmental Stress. Chilling, Freezing, and High Temperature Stresses. Vol. I. New York, Academic Press.

Macedo JF. 1997. O gênero Hedychium Koenig (Zingiberaceae) no Estado de Minas Gerais. Daphne 7: 27- 31.

Maricle BR, Lee RW. 2002. Aerenchyma development and oxygen transport in the estuarine cordgrasses Spartina alterniflora and S. anglica. Aquatic Botany 74: 109-120.

Mendelssohn IA, Mckee KL, Patrick WH. 1981. Oxygen Deficiency in Spartina alterniflora Roots: Metabolic Adaptation to Anoxia. Science 214: 439-441.

Pan Y, Xie Y, Chen X, Li F. 2012. Effects of flooding and sedimentation on the growth and physiology of two emergent macrophytes from Dongting Lake wetlands. Aquatic Botany 100: 35-40.

Sims B. 1974. A simple method of preparing 1-2 $\mu \mathrm{m}$ sections of large tissue blocks using glycol methacrylate. Journal of Microscopy 101: 223-227.

Soares J, Silva D, Lima M. 2003. Current state and projection of the probable original vegetation of the São Carlos region of São Paulo State, Brazil. Brazilian Journal of Biology 63: 527-536.

Sultan SE. 2003. Phenotypic plasticity in plants: a case study in ecological development. Evolution \& Development 5: 25-33.

Teal J, Teal M. 1969. The Dominant Spartinas. In: Teal J, Teal M. (eds.) Life and Death of the Salt Marsh. Boston, Little, Brown, and Company. p. 84-101.

VanWallendael A, Hamann E, Franks SJ. 2018. Evidence for plasticity, but not local adaptation, in invasive Japanese knotweed (Reynoutria japonica) in North America. Evolutionary Ecology 32: 395-410.

Weber E. 2011. Strong regeneration ability from rhizome fragments in two invasive clonal plants (Solidago canadensis and S. gigantea). Biological Invasions 13: 2947-2955.

Williams JL, Auge H, Maron JL. 2008. Different gardens, different results: native and introduced populations exhibit contrasting phenotypes across common gardens. Oecologia 157: 239-248. 